\title{
LACK OF COVALENT BINDING TO RAT LIVER DNA OF THE HYPOLIPIDEMIC DRUGS CLOFIBRATE AND FENOFIBRATE
}

\author{
A. VON DÄNIKEN, W.K. LUTZ and C. SCHLATTER \\ Institute of Toxicology, Swiss Federal Instirute of Technology and University of Zurich, CH-8603 \\ Schwerzenbach (Switzerland)
}

(Received June 22nd, 1980)

(Accepted September 21st, 1980)

\section{SUMMARY}

${ }^{14} \mathrm{C}$-Labelled clofibric acid and fenofibric acid were administered p.o. to $200 \mathrm{~g}$ male and female rats. After $10 \mathrm{~h}$, liver nuclear DNA and protein were isolated and the radioactivity was determined. Binding to protein was clearly measurable whereas no binding to DNA could be detected from any drug. A comparison of the limit of detection of such DNA binding with well-known chemical carcinogens revealed that the known hepatocarcinogenicity of clofibrate cannot be based upon an initiating, DNA damaging, mode of action but must be due to other, nongenotoxic, mechanisms such as peroxisome proliferation, hepatomegaly, or cytotoxicity due to protein binding. The risk assessment in man and the interpretation of the carcinogenicity data for rodents are discussed.

\section{INTRODUCTION}

Clofibrate (ethyl- $\alpha$-p-chlorophenoxyisobutyrate), the most widely used hypolipidemic drug in the U.S. and Europe [1] has been shown to induce hyperplastic and neoplastic changes in rat liver $[2,3]$. Epidemiologic investigations in man have revealed an increased incidence of various malignant neoplasms but the findings are not statistically significant [4]. Fenofibrate (isopropyl-[4' (p-chlorobenzoyl)-2-phenoxy-2-methyl]-propionate; procetofene; Lipanthyl ${ }^{\circledR}$; LF 178),

\footnotetext{
Please send correspondence to: Dr. W.K. Lutz, Institute of Toxicology, ETH/Univ. of Zürich, CH-8603
} Schwerzenbach (Switzerland).

Abbreviation: $\mathrm{CBI}$, covalent binding index. 
structurally related to clofibrate, is about 6 times more active as a hypolipidemic agent [5]. No reports on long-term carcinogenicity studies with fenofibrate have been published.

These two and other hypolipidemic drugs cause a marked increase of liver peroxisomes in rodents accompanied by a marked hepatomegaly [6-8], and it was postulated in a recent report [9] that peroxisome proliferators might represent a novel class of carcinogens.

One main characteristic of most organic chemical carcinogens is their ability to undergo covalent interactions with the DNA of the target organ. It has been shown that hypolipidemic peroxisome proliferators are negative in the Ames test and in the lymphocyte $\left[{ }^{3} \mathrm{H}\right]$ thymidine assay [10]. Formation of reactive metabolites and their interaction with macromolecules in animals has not yet been studied.

We report here that clofibric acid (I) or fenofibric acid (II), the pharmacologically active forms [11] and most important metabolites of clofibrate and fenofibrate [12], respectively, do not interact with rat liver DNA after oral administration.<smiles>CC(C)(Oc1ccc(Cl)cc1)C(=O)O</smiles>

I<smiles>CC(C)(Oc1ccc(C(C)(C)c2ccc(Cl)cc2)cc1)C(=O)O</smiles>

II

\section{MATERIALS AND METHODS}

$\left[{ }^{14} \mathrm{C}\right]$ Clofibric acid (I) was prepared by the Commissariat à l'Energie Atomique, Gif-sur-Yvette, France, with a specific activity of $22 \mathrm{mCi} / \mathrm{mmol}$. [ ${ }^{14} \mathrm{C}$ ]Fenofibric acid (II) was synthesized by Luu Duc, Laboratoire de Chimie et de Pharmacie, Université Scientifique et de Médecine de Grenoble, La Trouche, France, with a specific activity of $5.82 \mathrm{mCi} / \mathrm{mmol}$. The compounds were labelled at the positions indicated in the structural formula. The purity was $>97 \%$, as determined by thinlayer chromatography on silicagel plates with benzene-ethanol-acetic acid, $80: 12: 5$. For the low-dose experiment, the labelled compounds were used undiluted. For the high-dose experiment, they were diluted with inactive material (Laboratoires Fournier S.A., Dijon, France) to specific activities of $2.63 \mathrm{mCi} / \mathrm{mmol}$ and 2.82 $\mathrm{mCi} / \mathrm{mmol}$ for the clofibric and fenofibric acid, respectively. The compounds were administered p.o. in $0.5 \mathrm{ml}$ dimethyl sulfoxide to Sprague-Dawley-derived SIV 50 rats weighing about $200 \mathrm{~g}$. They were fed with Nafag laboratory chow No 890 (Nafag AG, Gossau, Switzerland) and were given tap water ad lib. $10 \mathrm{~h}$ after the administration, the rats were killed by open-heart puncture under ether anesthesia, the livers were excised, and a nuclear fraction was prepared according to Viviani et al. [13]. Nuclear protein was precipitated 4 times with acetone and purified by dialysis and one more acetone precipitation step [14]. DNA was isolated by the 
method of Markov and Ivanov [15] with some modifications [14]. The highly purified DNA (less than $0.1 \%$ protein) was dissolved in $4 \mathrm{ml} 0.014 \mathrm{M}$ phosphate buffer (pH 6.8) and the scintillation counting was performed after addition of $10 \mathrm{ml}$ InstaGel (Packard Instruments, Downers Grove, IL, USA). The amount of DNA was determined by assuming an absorbance of 20 at $260 \mathrm{~nm}$ for a solution of $1 \mathrm{mg}$ DNA/ml. The protein was dissolved in $4 \mathrm{ml} 1 \%$ sodium dodecyl sulfate and counted by adding $1 \mathrm{ml}$ to $10 \mathrm{ml}$ Insta-Gel. The amount of protein was measured by the method of Lowry et al. [16].

\section{RESULTS AND DISCUSSION}

Compounds I and II, both ${ }^{14} \mathrm{C}$-labelled in the indicated position, were administered in low and high dose levels by gastric intubation to young adult rats. Nuclear DNA and protein were isolated from the livers after $10 \mathrm{~h}$ and the radioactivity of the macromolecules was determined. Whereas on the protein a radioactivity in the order of 9 to $78 \mathrm{dpm} / \mathrm{mg}$ could be detected, the corresponding DNA values were just above the limit of detection (clofibric acid, high dose) or not measurable at all (all other cases) (Table I).

Two dose levels were used in our binding experiments to detect possible saturation of metabolic pathways which might lead to qualitative changes in the pattern of metabolites.

The minute radioactivity detected on the DNA after clofibrate administration most probably does not indicate covalent binding of the drug to DNA but is due to biosynthetic incorporation of radioactivity. After oral administration of clofibric acid labelled at the terminal carboxyl group, $0.85 \%$ of the dose (high-dose experiment) was exhaled within $10 \mathrm{~h}$ as ${ }^{14} \mathrm{CO}_{2} . \mathrm{CO}_{2}$ is one of the precursors for the purine biosynthesis so that the radioactivity detected on the DNA might well have been incorporated. A control experiment was therefore performed: After oral administration of $15 \mathrm{mg} / \mathrm{kg}{ }^{14} \mathrm{CH}_{3} \mathrm{OH}$ to rats, $80 \%$ of the radioactivity was exhaled as ${ }^{14} \mathrm{CO}_{2}$. The radioactivity which was incorporated into liver DNA, $12 \mathrm{~h}$ after this administration, corresponded to an apparent CBI of 170. These results were compatible with the above-mentioned hypothesis. With fenofibric acid, the label is not in the terminal carboxyl group and a release of radioactivity into the pool of nucleic acid precursors is much less likely. This is in agreement with the much smaller fraction of $0.06 \%$ of the radioactive dose that is exhaled as ${ }^{14} \mathrm{CO}_{2}$.

In order to compare chemicals of varying DNA-binding abilities, the binding potency is expressed as a CBI = DNA damage/dose [17]. The strongest hepatocarcinogenic compounds with a genotoxic, initiating mode of action, e.g. aflatoxin $\mathrm{B}_{1}$ or dimethylnitrosamine, exhibit a CBI in the order of $10^{3}$ to $10^{4}$. Moderate hepatocarcinogens like 2-acetylaminofluorene and vinyl chloride show a CBI of about $10^{2}$. As estimated from the long-term carcinogenicity data with clofibrate [3], and by using a linear relationship between carcinogenicity and CBI [18], a CBI of 10 


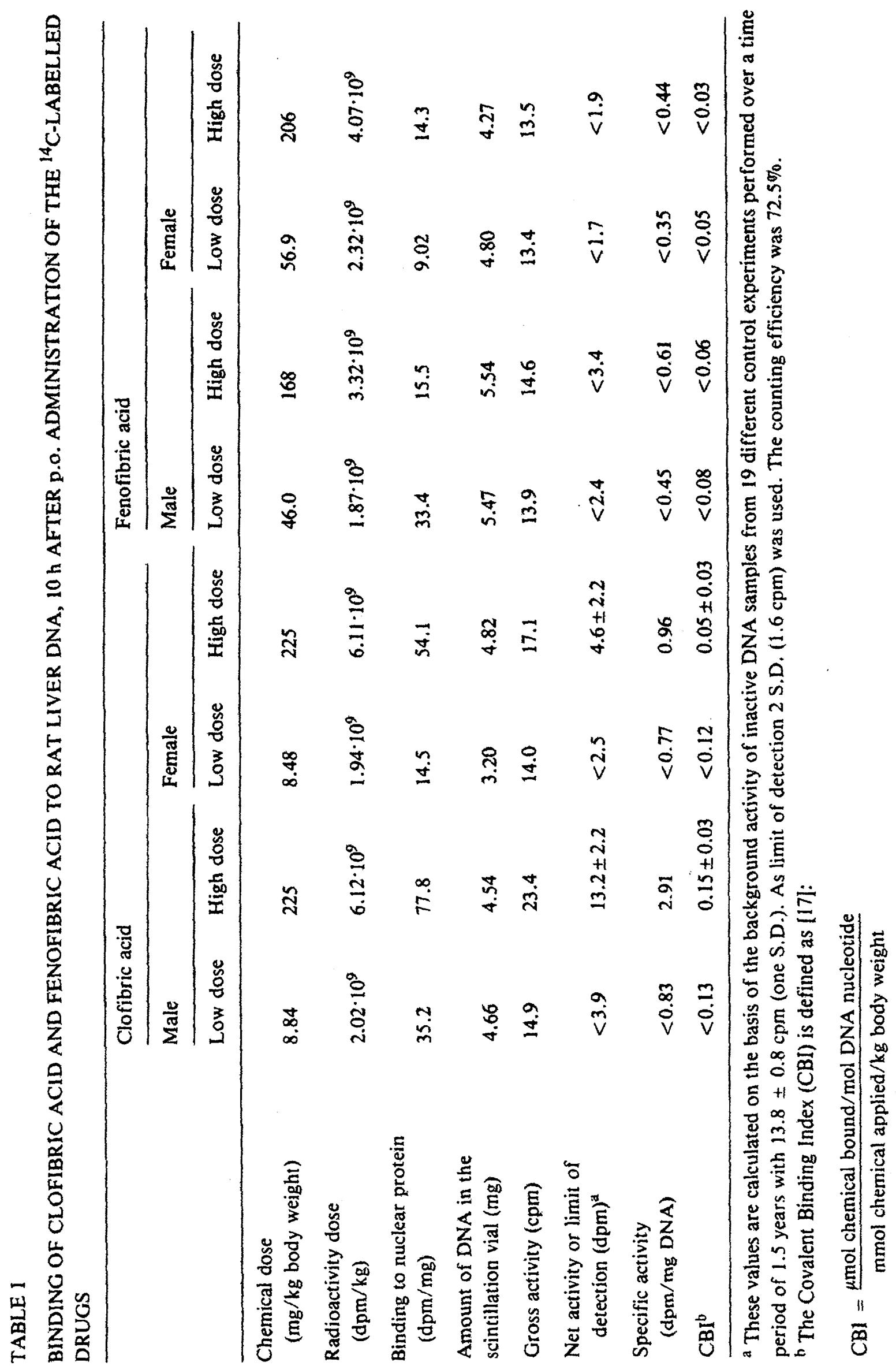


would be expected for clofibrate if the mode of carcinogenic action of this drug were by DNA binding. However, the actually measured maximum possible CBI for clofibric acid, $\mathbf{0 . 1 5}$, is about 50 times below that value and is probably even lower if the biosynthetic part of the radioactivity is deducted. A genotoxic mode of the carcinogenic action is therefore unlikely and a non-genotoxic activity seems to be the reason for the observed liver tumors in the rat after treatment with clofibrate. The limit of detection of a DNA binding by fenofibric acid is another factor of 5 lower. Together with the knowledge that therapeutic doses with this drug are about 6 times lower than with clofibric acid [5], a maximum possible DNA damage (CBI $\times$ dose) from fenofibric acid is therefore regarded negligible and a potential carcinogenicity of this drug must be due to non-genotoxic mechanisms.

Protein binding is not as well correlated with tumorigenicity as is DNA binding [19]. Protein binding tends to lead to cytotoxicity and it is conceivable that the regenerating processes elicited from a high dose of a cytotoxic drug might have a promoting effect on any pre-existing pre-cancerous lesion set by ubiquitous genotoxic agents.

The present data exclude somatic mutations as a carcinogenic mode of action of these two drugs. A risk assessment for man must therefore be based upon their cancer-promotive activities. Many other frequently used compounds such as phenobarbital or halogenated pesticides show a similar mode of action. Threshold levels, non-linear dose-tumor relationships and a strong correlation with cell metabolism are more likely to be found with promoting activities than with initiating, genotoxic compounds. An extrapolation of any carcinogenicity data from rats to man must therefore await a comparison over a wide dose range of a number of biochemical effects of these drugs, viz., induction of microsomal enzymes, hypertrophy and hyperplasia of the liver.

\section{ACKNOWLEDGEMENT}

We thank the Laboratoires Fournier S.A., Dijon, France, for kindly supplying the labelled drugs.

\section{REFERENCES}

1 R.J. Havel and J.P. Kane, Drugs and lipid metabolism: clofibrate, Annu. Rev. Pharmacol., 13 (1973) 291-300.

2 J.K. Reddy and S.A. Qureshi, Tumorigenicity of the hypolipidemic peroxisome proliferator ethyl- $\alpha$ p-chlorophenoxyisobutyrate (clofibrate) in rats, Br. J. Cancer, 40 (1979) 476-482.

3 D.J. Svoboda and D.L. Azarnoff, Tumors in male rats fed ethyl chlorophenoxyisobutyrate, a hypolipidemic drug, Cancer Res., 39 (1979) 3419-3428.

4 M.F. Oliver, J.A. Heady, J.N. Morris and J. Cooper, A co-operative trial in the primary prevention of ischaemic heart disease using clofibrate, Br. Heart J., 40 (1978) 1069-1118. 
S J. Gurrieri, M. Le Lous, F.J. Renson, C. Tourne, H. Voegelin, B. Majoie, and E. Wülfert, Antilipidemic drugs, Part 2: Experimental study of a new potent hypolipidemic drug, isopropyl-[4' -(p-chlorobenzoyl)-2-phenoxy-2-methyl]-propionate (LF 178), Arzneimittel-Forsch., 26 (1976) 889-894.

6 R. Hess, W. Staubli and W. Riess, Nature of the hepatomegalic effect produced by ethylchlorophenoxy-isobutyrate in the rat, Nature, 208 (1965) 856-858.

7 J.K. Reddy and T.P. Krishnakantha, Hepatic peroxisome proliferation: Induction by two novel compounds structurally unrelated to clofibrate, Science, 190 (1975) 787-789.

8 S.D. Barnard, J.A. Molello, W.J. Caldwell and J.E. LeBeau, Comparative ultrastructural study of rat hepatocytes after treatment with the hypolipidemic agents probucol, clofibrate, and fenofibrate, J. Toxicol. Environ. Health, 6 (1980) 547-557.

9 J.K. Reddy, D.L. Azarnoff and C.E. Hignite, Hypolipidaemic hepatic peroxisome proliferators form a novel class of chemical carcinogens, Nature, 283 (1980) 397-398.

10 J.R. Warren, V.F. Simmon and J.K. Reddy, Properties of hypolipidemic peroxisome proliferators in the lymphocyte $\left[{ }^{3} \mathrm{H}\right]$ thymidine and Salmonella mutagenesis assay, Cancer Res., 40 (1980) 36-41.

11 C. Harvengt and J.P. Desager, Pharmacokinetic study and bioavailability of three marketed compounds releasing $p$-chlorophenoxyisobutyric acid (CPIB) in volunteers, Int. J. Clin. Pharmacol., 14 (1976) 113-118.

12 R.R. Brodie, L.F. Chasseaud, F.F. Elsom, E.R. Franklin and T. Taylor, Antilipidemic drugs, Part 4: The metabolic fate of the hypolipidemic agent isopropyl-[4'-(p-chlorobenzoyl)-2-phenoxy-2methyl]-propionate (LF 178) in rats, dog and man, Arzneimittel-Forsch., 26 (1976) 896-901.

13 A. Viviani, W.K. Lutz and C. Schlatter, Time course of the induction of aryl hydrocarbon hydroxylase in rat liver nuclei and microsomes, Biochem. Pharmacol., 27 (1978) 2103-2108.

14 A. von Däniken, W.K. Lutz, U. Friederich and C. Schlatter, Tests for mutagenicity and in vivo covalent binding to DNA or protein of the riot control agent $o$-chlorobenzylidene malononitrile (CS), submitted to Arch. Toxicol.

15 G.G. Markov and I.G. Ivanov, Hydroxyapatite column chromatography in procedures for isolation of purified DNA, Anal. Biochem., 59 (1974) 555-563.

16 O.H. Lowry, N.J. Rosebrough, A.L. Farr and R.J. Randall, Protein measurement with the Folin phenol reagent, J. Biol. Chem., 193 (1951) 265-275.

17 W.K. Lutz, In vivo covalent binding of organic chemicals to DNA as a quantitative indicator in the process of chemical carcinogenesis, Mutation Res., 65 (1979) 289-356.

18 W.K. Lutz, Constitutive and carcinogen-derived DNA binding as a basis for the assessment of potency of chemical carcinogens, in: R. Snyder, D.V. Parke, J.J. Kocsis and D.J. Jollow (Eds.), Biological Reactive Intermediates II, Plenum, New York, 1981, in press.

19 P. Brookes, Role of covalent binding in carcinogenicity, in: D.J. Jollow, J.J. Kocsis, R. Snyder and H. Vainio (Eds.), Biological Reactive Intermediates, Plenum, New York, 1977, pp. 470-480. 